\title{
OROFACIAL PAIN - DIAGNOSTIC AND THERAPEUTIC CHALLENGES
}

\author{
Tomislav Badel ${ }^{1}$, Dijana Zadravec², Vanja Bašić Kes ${ }^{3}$, Mia Smoljan², \\ Sandra Kocijan Lovko ${ }^{4}$, Iris Zavoreo ${ }^{3}$, Ladislav Krapac ${ }^{5}$, Sandra Anić Milošević ${ }^{6}$
}

${ }^{1}$ Department of Removable Prosthodontics, School of Dental Medicine, University of Zagreb, Zagreb, Croatia; ${ }^{2}$ Department of Diagnostic and Interventional Radiology, Sestre milosrdnice University Hospital Center, University of Zagreb, Zagreb, Croatia; ${ }^{3}$ Department of Neurology, Sestre milosrdnice University Hospital Center, University of Zagreb, Zagreb, Croatia; ${ }^{4}$ Psychiatry Hospital “Sv Ivan”, Zagreb, Croatia;

${ }^{5}$ Academy of Medical Sciences of Croatia, Department of Public Health, Zagreb, Croatia; ${ }^{6}$ Department of Orthodontics, School of Dental Medicine, University of Zagreb, Zagreb, Croatia

SUMMARY - The concept of diagnostics and therapy of musculoskeletal and neuropathic diseases of the stomatognathic system, which are the subject of this paper, has been developing for decades. It can be said that in order to avoid misunderstanding, the orofacial pain as a clinical problem, in the narrower sense, involves non-odontogenic and non-malignant causes of orofacial region. In this study, the results of clinical diagnosis of the population of 557 consecutive patients with orofacial pain based on multidisciplinary diagnostics were evaluated. $15.6 \%$ of patients have given up on the participation in the study. It has been shown that the patients who dropped out of the study were significantly older $(\mathrm{p}=0.0411)$ than those who agreed to participate, but there was no difference in gender ratio $(\mathrm{p}=0.185)$ since the proportion of female patients prevailed. In an analysis of $84.4 \%$ of patients participating in the study, the elevated anxiety values were established (mean value on STAI 1 was 39.2 and STAI 2 was 41.1) and statistical significance was found in correlation between elevated anxiety and intensity of pain as shown on visual analogue scale on open mouth $(\mathrm{p}<0.0001)$. Compared to the age, the statistical significance was for STAI $1(p=0.0097)$ but not for STAI $2(p=0.5599)$. The most common form of therapy is Michigan stabilization splint: for disc displacement of temporomandibular joint (TMJ) in $38.9 \%$ of patients and in combination with physiotherapy in $18.7 \%$ of patients; for osteoarthritis of TMJ in $28.4 \%$ and in combination with physiotherapy in $26.4 \%$ of patients. The treatment with anticonvulsant drugs for trigeminal neuralgia predominates in $54.3 \%$ of patients, which is combined with acupuncture in $25.7 \%$ of patients and only acupuncture in $17.1 \%$ of patients. In this study, a multidisciplinary co-operation in initial diagnostics and differential was designed to develop subspecialist knowledge on orofacial pain.

Key words: orofacial pain, temporomandibular joint, anxiety, trigeminal neuralgia

\section{Introduction}

Generally, the pathology of orofacial pain is most commonly caused by the disease of the teeth (odonto-

Correspondence to: Dijana Zadravec, DMD, $\mathrm{PhD}$, Department of Diagnostic and Interventional Radiology, Sestre milosrdnice University Hospital Center, University of Zagreb, Vinogradska cesta 29, HR-10000 Zagreb, Croatia

E-mail: zadravec@sfzg.hr genic pain), which is a domain of dental medicine and it should not be a diagnostic-therapeutic challenge in itself. Apart from dental caries and periodontal diseases, musculoskeletal and neuropathological diseases are the most common cause of orofacial pain ${ }^{1,2}$. The relationship between the proprioceptive pattern of joint functioning and muscle pain-forming functioning is best described by the term encompassing a common name of myoarthropathy of the masticatory sys- 
tem according to Graber and Palla ${ }^{3}$, while temporomandibular disorders (TMDs) emphasizes the disorder (functions) as a dominant clinical determinant of the patient's symptoms.

Magnetic resonance imaging (MRI) is a radiological examination as the gold standard for temporomandibular joint (TMJ) by which it is possible to analyze the soft tissue, especially the disc. MRI is an unavoidable diagnostic procedure for visual joint-effusion detection, where effusion can be part of osteoarthritis, rheumatoid arthritis or a separate finding in painful TMJ pathology ${ }^{4}$. Most commonly, the initial treatment of TMDs includes an occlusal splint, physiotherapy and the use of non-steroidal anti-inflammatory drugs (NSAIDs) $)^{5-7}$.

Neuropathic pain is pain initiated or caused by a lesion of the peripheral or/and central nervous system manifesting with sensory symptoms and signs. Trigeminal neuralgia is characterized by unilateral disorder characterized by short-term attacks of pain such as an electrical shock which suddenly emerges and stops, and is limited to the innervation area of one or more trigeminal nerve branches ${ }^{8}$. Persistent pain is the second neuropathic entity occurring in the orofacial region. Unlike trigeminal neuralgia, this pain is more prolonged or persistent, diffused more widely in the affected area, and does not depend strictly on the area of innervation of trigeminal nerve branches as well as the median line of the body 9 .

In the framework of the Craniomanidbular Dysfunction and Occlusion research project, since 2001, MRI was implemented in the Department of Removable Prosthodontics at School of Dental Medicine and Department of Diagnostic and Interventional Radiology at Clinical Hospital "Sestre milosrdnice" (Both are part of the University of Zagreb, Zagreb) for the patients with orofacial pain. The first idea of prosthetic clinicians was to implement a scientific study for the needs of writing a dissertation, which became the only manuscript published as a monograph at the School of Dental Medicine in Zagreb ${ }^{10}$. In this study, the results of clinical diagnostics of the population of Croatian patients with orofacial pain based on multidisciplinary diagnostics were evaluated.

\section{Materials and methods}

This study population consisted of 557 consecutive patients (mean age $42.32 \pm 17.72$ years, range of age
$10-88$ years; 472 or $84.7 \%$ of females) who were referred between 2001 and 2017 to the Department of Removable Prosthodontics. For the purpose of obtaining a differential diagnosis, part of the patients was referred from the Clinic for Neurology and the Sestre milosrdnice University Hospital Center as a clinical basis for neuropathic orofacial pain. Co-operation with rheumatologic-physiatric practice has been developed, which has enabled the clinical symptoms of TMJ to be included as part of a generalized clinical picture of a patient with a confirmed diagnosis of inflammatory rheumatic disease. Central data for patients in diagnosis phase, records of treatment modalities and collection of follow-up data over a period of 16 years was performed by a single examiner (T.B) for orofacial diagnostics ${ }^{10}$. Prior to this investigation, all participants had signed an informed consent, and the study was approved by the Ethics Committee, School of Dental Medicine, University of Zagreb, Croatia.

The inclusion criteria for 'disc displacement' were pain and clicking or a history of clicking, and limited mouth opening. The inclusion criteria for 'osteoarthritis' were pain and crepitation with or without limited mouth opening. All patients underwent a comprehensive standardized examination that conformed to the RDC (Research Diagnostic Criteria)/TMD and DC (Diagnostic Criteria)//TMD which includes a clinical examination in Axis $\mathrm{I}^{11,12}$. The methods of manual functional analysis were additionally applied ${ }^{10}$. Manual functional analysis is particularly stressed in the evaluation of the condition of the stomatognathic system prior to major irreversible procedures in order to avoid delayed detection of more or less pronounced clinical signs and symptoms of TMDs which would not be recognized and treated on time in such a case ${ }^{10}$. Previous pain duration suffered by patients prior to the first examination was recorded as well as pain intensity on a visual-analogue scale (VAS; 0 , painless condition; 10 , the strongest pain ever experienced) in open mouth position only for temporomandibular pain itself and not for neuropathic orofacial pain. Clinical examination of the stomatognathic system included panoramic $\mathrm{x}$-ray imaging and a clinical examination of dental status. For patients with neuropathic pain and already established diagnoses, such as trigeminal neuralgia, it was necessary to determine possible comorbidity with TMJ-disorder, including the finding of TMJ subluxation $^{12}$. 


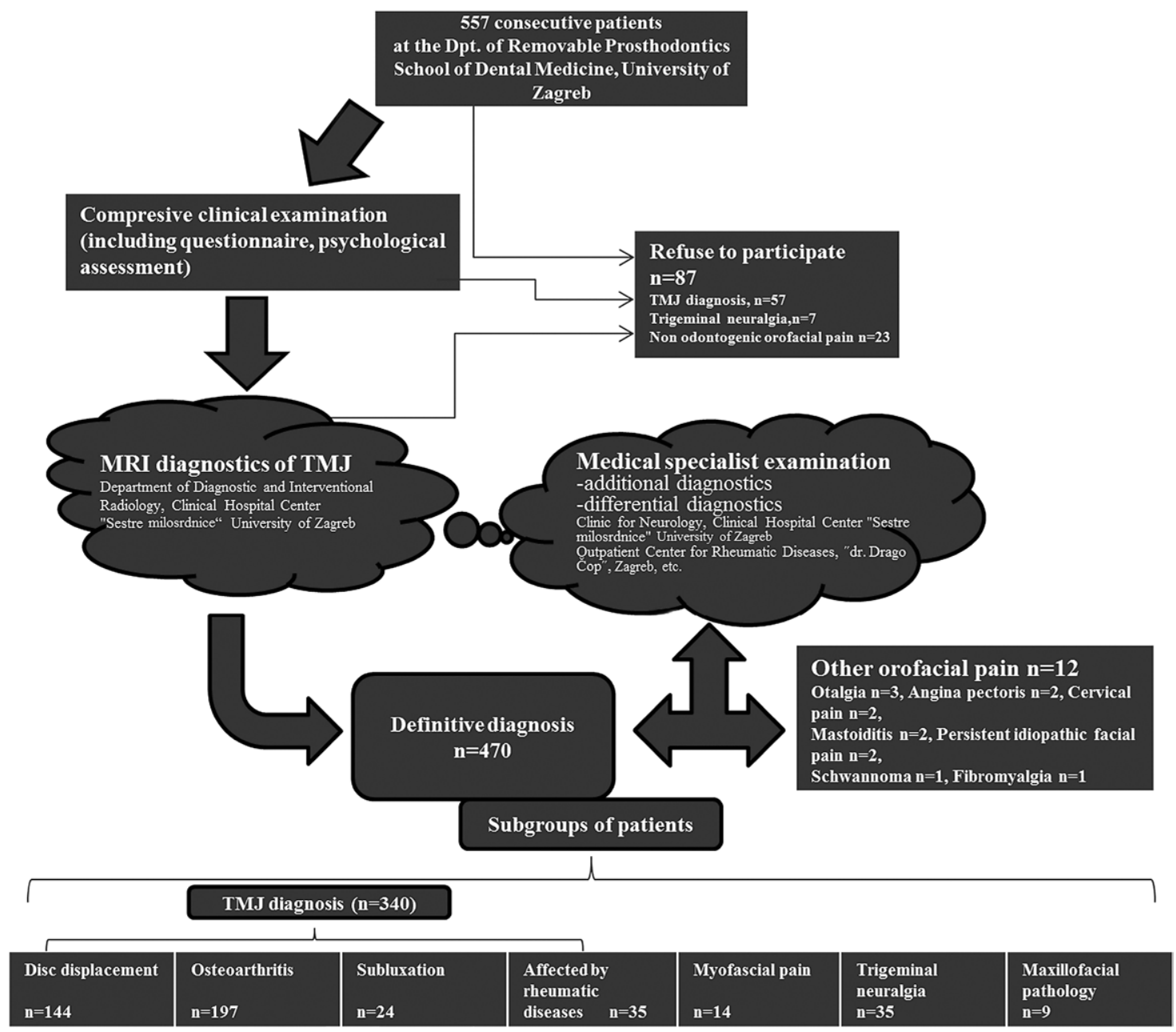

Fig. 1. Distribution of all patients during the study period and diagnostic subgroups of patient included in the study. MRI, magnetic resonance imaging; TMJ, temporomandibular joint.

The definitive diagnosis of TMDs and choosing the appropriate diagnostic subgroup were made according to the MRI findings: the primary diagnosis of disc displacement did not include clinical signs or radiological symptoms of osteoarthritis, whereas in the subgroup of patients with a primary diagnosis of osteoarthritis there was a possible co-morbidity with disc displacement.

The MRI examination was performed with the following spin-echo-sequent parameters using a $1 \mathrm{~T}$ scanner Magnetom Harmony (Siemens, Erlangen, Germany): $\mathrm{T}_{1}$ weighted image TR/TE 450/12, $\mathrm{T}_{2}$ weighted image TR 3000/TE 66, field of view of 160 x 160 , matrix of $256 \times 192$ and $3 \mathrm{~mm}$ slice), and a $1.5 \mathrm{~T}$ unit "Avanto" (Siemens, Germany) with parameters of the sequences: T1 weighted (TR 380-410/TE 9,4-15; matrix $410 \times 512 ; 180 \times 180$ field of view) and proton density (PD) weighted images (TR 2800/TE 90; matrix $320 \times 320 ; 160 \times 160$ field of view), with a $2 \mathrm{~mm}$ thickness. All subjects were scanned in the closed mouth position and the open mouth position. The angle of the parasagittal imaging is individually determined by the angle shown on the individual angulated layers of the axial and coronal slice. All MR-images were evaluated by a radiologist (D.Z) and a dentist (T.B.) who has a vast experience in MRI and TMJ. The correspondences of the MRI findings were calibrated by two radiologists. This was done independently of the clinical condition of the individual patient and was evaluated by the Cohen kappa index $(\kappa=0.80)$

The psychological assessment was carried out by Spielberger's State-Trait Anxiety Inventory (STAI) 
Form $\mathrm{Y}^{13}$. STAI is a self-reported scale for measuring anxiety. All items are rated on a 4-point scale. The range of scores is $20-80$, the higher the score indicating greater anxiety. STAI 1 test measures anxiety as a subjective state, a feeling lasting for a week, including the day of testing, and STAI test 2 measures anxiety as a relatively stable individual characteristic during life in general.

The statistical data analysis was performed by STATISTICA (StatSoft Inc., Tulsa, Oklahoma, USA) program. $\mathrm{P}$ values less than 0.05 were considered significant.

\section{Results}

Out of the total number of patients $(n=557)$ in different stages of treatment (Fig.1), a total of 87 patients dropped out or $15.6 \%$ (mean age \pm standard deviation (SD) $45.9 \pm 17.1$ years, range of age $15-81$ years, $78.2 \%$ of females, and the gender ratio female: male was 3.6:1). A statistically significant difference in age ( $t-$ test 2.0478 (df595); $p=0.0411$ ) was found between the total number of the patients who dropped out $(n=87)$ and those who gave consent to participate in the study $(\mathrm{n}=470$, mean age $\pm \mathrm{SD}$ was $41.7 \pm 17.8$ years, range of age $10-88$ years, $86 \%$ of females, gender ratio female: male was 6.1:1). However, the gender ratio did not show a statistically significant difference (chi-square test (df1) $=1.7567 ; \mathrm{p}=0.185$ ).

Some patients gave up on the participation in the study on initial examination and information gathering after they had been explained that the data would be collected for scientific purposes, and some patients dropped out after taking the MRI of TMJ. Table 1 shows data for subgroups of the patients who dropped out of the study. The symptoms of TMJ disorders dominated in these patients (Fig. 1). There were 13 patients with TMJ-disorder, 6 with trigeminal neuralgia and 4 patients with other orofacial pains. The number of patients in a group who refused to participate was lower for patients undergoing an initial examination. For patients who gave up after clinical examination, there were 28 patients with TMJ-disorder, one patient with trigeminal neuralgia and 3 patients with other orofacial pains.

In the subgroup of patients who dropped out after having been diagnosed by taking MRI for TMJ, there were 16 of them with TMJ-disorder and 16 with other
Table 1. Subgroups of patients who refuse to participate

\begin{tabular}{|l|l|l|l|}
\hline $\begin{array}{l}\text { Subgroups } \\
\text { of excluded } \\
\text { patients }\end{array}$ & $\begin{array}{l}\text { During } \\
\text { the initial } \\
\text { examination }\end{array}$ & $\begin{array}{l}\text { After } \\
\text { clinical } \\
\text { examination }\end{array}$ & $\begin{array}{l}\text { After } \\
\text { diagnostics } \\
\text { by MRI } \\
\text { of TMJ }\end{array}$ \\
\hline $\mathrm{n}$ & 23 & 32 & 32 \\
\hline $\begin{array}{l}\text { Mean } \\
\text { age } \pm S D \\
\text { (years) }\end{array}$ & $48.3 \pm 16.3$ & $41.7 \pm 16.0$ & $48.4 \pm 18.4$ \\
\hline $\begin{array}{l}\text { Range of age } \\
\text { (years) }\end{array}$ & $21-81$ & $15-74$ & $16-76$ \\
\hline Part of female & $73.9 \%$ & $81.3 \%$ & $78.1 \%$ \\
\hline $\begin{array}{l}\text { Gender ratio } \\
\text { (female:male) }\end{array}$ & $2.8: 1$ & $4.3: 1$ & $3.6: 1$ \\
\hline
\end{tabular}

MRI, magnetic resonance imaging; TMJ, temporomanidbular joint; $n$, number of patients; SD, standard deviation

orofacial pains. In patients with orofacial pain, it was not possible to carry out additional diagnostics and data collecting from some specialist examinations to diagnose differential causes of pain due to their lack of collaboration. These patients were also reluctant to participate in the study by responding to additional examinations and collecting their medical data.

A group of patients $(n=470)$ who gave consent to participate in the study were divided based on the set of definitive diagnoses on 8 diagnostic subgroups. Patients with TMJ-related diagnoses $(n=340)$ have the largest share in a patient with orofacial pain in general (Fig. 1, Table 2). Of this, osteoarthritis diagnosis (which also includes the comorbidity disc displacement) is the most comprehensive diagnosis category ( $n=197)$. Degenerative involvement of other joints with osteoarthritis (polyarthritis) has not been taken into account in the presentation of this study in this paper. The patients with disc displacement followed $(n=144)$.

Within the scope of interdisciplinary medical and dental cooperation, the diagnostics did not exclude systemic involvement of the joints, as well as symptomatic TMJs with inflammatory rheumatic diseases. This group consisted of 35 patients who had already been diagnosed with rheumatic disease or were diagnosed during diagnostic procedures (rheumatoid arthritis, ankylosing spondylitis, Sjogren's syndrome, psoriatic arthritis, mixed connective tissue disease, and Crohn's disease). The TMJ subluxation diagnosis was 
Table 2. Subgroups of patients who participate in the study

\begin{tabular}{|c|c|c|c|c|c|c|c|c|}
\hline \multirow{2}{*}{ Subgroups of patients } & \multirow{2}{*}{ n (\%) } & \multicolumn{4}{|l|}{ Age (years) } & \multirow{2}{*}{$\begin{array}{l}\text { Range } \\
\text { of age (years) }\end{array}$} & \multirow{2}{*}{\begin{tabular}{|l} 
Part \\
of female
\end{tabular}} & \multirow{2}{*}{$\begin{array}{l}\text { Gender ratio } \\
\text { (female:male) }\end{array}$} \\
\hline & & Mean \pm SD & Q1 & Median & Q2 & & & \\
\hline Disc displacment of TMJ & $\begin{array}{l}144 \\
(30.6 \%)\end{array}$ & $29.9 \pm 13.6$ & 21 & 25 & 36 & $10-84$ & $84.0 \%$ & $\begin{array}{l}121: 23 \\
5.3: 1\end{array}$ \\
\hline Osteoarthritis of TMJ & \begin{tabular}{|l}
197 \\
$(41.9 \%)$
\end{tabular} & $47.4 \pm 17.2$ & 33 & 50 & 61 & $15-83$ & $93.4 \%$ & $\begin{array}{l}184: 13 \\
14.2: 1\end{array}$ \\
\hline Subluxation of TMJ & \begin{tabular}{|l|}
24 \\
$(5.1 \%)$
\end{tabular} & $32.3 \pm 13.2$ & 23,3 & 26,5 & 41,5 & $16-62$ & $75.0 \%$ & $\begin{array}{l}18: 6 \\
3: 1\end{array}$ \\
\hline $\begin{array}{l}\text { TMJ affected by } \\
\text { rheumatic disease }\end{array}$ & $\begin{array}{l}35 \\
(7.5 \%) \\
\end{array}$ & $49.4 \pm 17.4$ & 31 & 51 & 64 & $14-78$ & $82.9 \%$ & $\begin{array}{l}29: 6 \\
4,8: 1\end{array}$ \\
\hline Myofascial pain & $\begin{array}{l}14 \\
(3.0 \%)\end{array}$ & $37.6 \pm 13.1$ & 29 & 33 & 42,3 & $23-69$ & $71.4 \%$ & $\begin{array}{l}10: 4 \\
2.5: 1\end{array}$ \\
\hline Trigeminal neuralgia & $\begin{array}{l}35 \\
(7.5 \%)\end{array}$ & $52.9 \pm 13.0$ & 45 & 51 & 61 & $25-88$ & $71.3 \%$ & $\begin{array}{l}26: 9 \\
2.9: 1\end{array}$ \\
\hline Maxillofacial pathology & $\begin{array}{l}9 \\
(1.9 \%)\end{array}$ & $51.0 \pm 20.8$ & 31 & 54 & 68,5 & $17-80$ & $77.8 \%$ & $\begin{array}{l}7: 2 \\
3.5: 1\end{array}$ \\
\hline Other orofacial pain & $\begin{array}{l}12 \\
(2.5 \%) \\
\end{array}$ & $49.0 \pm 11.7$ & 42 & 48 & 56,8 & $30-73$ & $75.0 \%$ & $\begin{array}{l}9: 3 \\
3: 1 \\
\end{array}$ \\
\hline
\end{tabular}

n, number of patients; TMJ, temporomanidbular joint; SD, standard deviation; Q1, 0,25-quantile; Q2, 0,75-quantile

Table 3. Statistically significant correlations of anxiety on STAI with age, previous pain duration, and pain intensity on VAS

\begin{tabular}{|c|c|c|c|}
\hline & Age & $\begin{array}{l}\begin{array}{l}\text { Previous pain } \\
\text { duration }\end{array} \\
\end{array}$ & Pain on VAS \\
\hline STAI 1 & $\begin{array}{l}\text { t-test } 2.5928 \\
(\mathrm{df} 938) \\
\mathrm{p}=0,0097\end{array}$ & $\begin{array}{l}\text { t-test } 8.5927 \\
(\mathrm{df} 938) \\
\mathrm{p}<0.0001\end{array}$ & $\begin{array}{l}\text { t-test } 8.5927 \\
(\mathrm{df938)} \\
\mathrm{p}<0.0001\end{array}$ \\
\hline STAI 2 & $\begin{array}{l}\text { t-test } 0.5832 \\
(d f 938) \\
p=0.5599 \mathrm{NS}\end{array}$ & $\begin{array}{l}\text { t-test 9,5607 } \\
(\mathrm{df938)} \\
\mathrm{p}<0.0001\end{array}$ & $\begin{array}{l}\text { t-test 9,5607 } \\
(\text { df938) } \\
p<0.0001\end{array}$ \\
\hline
\end{tabular}

STAI, State-Trait Anxiety Inventory; VAS, visual-analogue scale; NS, not significant

confirmed in 24 patients. In this study, based on the MRI, 14 patients were diagnosed only with myofascial pain of masticatory muscles. 35 patients had pains caused by trigeminal neuralgia (Table 3 ).

The smallest group comprised the patients with Eagle syndrome (6 patients, of whom 4 underwent surgery), two patients had a hyperplastic coronoid process of the mandible (one underwent surgery), and one patient with the synovial osteohondromatosis of TMJ underwent surgery. Their final diagnostics as well as the indication for surgery were in the field of maxillo- facial surgery. Other diagnoses of orofacial pain $(n=12)$ are presented in a separate subgroup (Fig. 1).

Myofascial pain was the most frequent among the comorbidities in the individual diagnostic subgroups of patients, which was also found in patients with disc displacement $(n=25)$, osteoarthritis $(n=24)$ and in subgroups where TMJ involvement with rheumatic diseases was found $(n=10)$. Then there is a comorbidity with trigeminal neuralgia (16 patients with osteoarthritis, 4 patients with TMJ affected with rheumatic disease, 2 patients from the subgroup of maxillofacial pathology, and one patient from the subgroup of disc displacement). Persistent idiopathic facial pain was found in subgroups with osteoarthritis $(n=19)$ and disc displacement $(n=1)$. The distribution of the patient by age and gender is presented in all 8 subgroups of $\mathrm{pa}^{-}$ tients in Table 2.

In the overall sample, a statistically significant correlation (t-test 42.8211 (df938); $\mathrm{p}<0.0001$ ) was found between the age of all subjects (mean age $\pm \mathrm{SD}$ : $41.7 \pm 17.8$ years) and intensity pain on VAS (mean value $\pm \mathrm{SD}$ was $6.4 \pm 1.7$, median value 6 , range of pain intensity on VAS: minimum 1, maximum 10).

For all patients involved in the study, previous pain duration in months experienced by patients before the first examination (mean value $\pm \mathrm{SD}$ was $21.3 \pm 43$.8, me- 
dian 24, ranging from 0.1 to 600 months) was statistically significantly correlated compared to the intensity of pain intensity at VAS (t-test 7.3718 (df938); $\mathrm{p}<0.0001$ ). Months of previous pain were statistically significantly dependent on the age of the patient $(\mathrm{t}-$ test 9.3233 (df938); $\mathrm{p}<0.0001$ ). For all patients in the study, the correlation between STAI 1 (mean value \pm SD was $39.2 \pm 10.4$ ) and general anxiety at STAI 2 (mean value $\pm S D$ was $41.1 \pm 9.5)$ is shown in Table 3 . There were no statistically significant correlations between the age of the total sample of patients and STAI 2.

The use of the therapy depended on the type of diagnosis since one of the first choices for diagnosis of TMJ was a fabrication of the Michigan stabilization splint. For a disc displacement of TMJ in 38.9\% of patients and a splint in combination with physiotherapy in $18.7 \%$ of patients, followed only by physiotherapy in $25.7 \%$ of patients, acupuncture in $1.4 \%$ of patients, removal of removable dentures in one patient $(0.7 \%)$ and $14.6 \%$ of patients who refused to be treated. The osteoarthritis of TMJ was treated by a splint in $28.4 \%$ of patients and in combination with physiotherapy in $26.4 \%$ of patients. Physiotherapy alone was applied in $32 \%$ of patients, removable dentures were applied in 4 patients (2.0\%), and $11.2 \%$ of patients did not want to be treated.

In the subgroup of patients with trigeminal neuralgia, the treatment with anticonvulsant drugs was applied in $54.3 \%$ of patients, anticonvulsant drugs in combination with acupuncture in $25.7 \%$ of patients and the treatment by acupuncture alone in $17.1 \%$ of patients. Only one patient $(2.95 \%)$ was treated with opioid non-steroidal anti-inflammatory drugs (NSAID).

\section{Discussion}

The World Health Organization devoted the second decade in a row to bone and joint diseases (20102020), thus highlighting the public health importance of chronic musculoskeletal pain ${ }^{14}$. Pain chronification poses a particular challenge in treatment of musculoskeletal disorders. Untreated, insufficiently treated or wrongly treated temporomandibular pain lasting more than 6 months is considered chronic rather than multiple occurrences of acute pain. Chronic pain is nonsomatic in origin and the long-lasting peripheral sensitization results in intensified pain sensation in noci- ceptors which leads to functional neuroplastic changes in the central nervous system ${ }^{9,15,16}$.

Inevitably, with a higher proportion of patients with TMDs their age and gender structure changes and the need for prosthetic rehabilitation of patients is less necessary, which has an impact on the planning of practical tasks within the course of removable prosthetic and clinical practicals for dental students ${ }^{17}$.

Clinical diagnostics is the basis of musculoskeletal disorder diagnostics which is, in the stomatognathic system, based on the so-called clinical gold standard $^{3,18,19}$. The importance of DC/TMD system is that it shows a possibility of defining certain diagnoses of TMDs wherein the diagnosis of one subgroup does not exclude the diagnosis from the other subgroup in the same patient ${ }^{11,12,20}$. Nevertheless, there are certain limitations because DC/TMD does not include a supplementary MRI. The DC/TMD Axis II does not include anxiety measuring, but the Spielberger's STAI is one easy-to-use instrument in practice and also a screening measure ${ }^{13,21}$.

The application of etiopathogenetic models of the origin of TMDs on certain patients with clinical signs and symptoms is not completely possible and therefore, the application of personalized/person-centered medicine concepts in chronic pain management is necessary ${ }^{9,22,23}$. Orofacial pain (musculoskeletal, neuropathic, neurovascular) has a prevalence of up to 22$26 \%$ in general population, out of which $7-11 \%$ have chronic pain ${ }^{2,8,24}$. The prevalence of pain in the TMJ and masticatory muscles is relatively low (around $2-7 \%)$. Emergency cases in oral surgery are mostly consequences of odontogenic complications and soft tissue injuries $(33.94 \%$ and $22.54 \%$ respectively), whereas TMJ disorders and trigeminal neuralgia account for less than $2 \%$ (1.63\% and $1.34 \%$ respectively) $2,25,26$.

For dental practice, it is most important to differentiate whether pain is odontogenic, since teeth involvement with neuropathic pains is dominant. Any oversight in initial dental diagnosis may result either in excessive treatments of teeth or removal of the susceptible tooth without solving the underlying problem of severe neuropathic pain. It has been observed that subluxation is a common finding in patients suffering from neuropathic pain ${ }^{2,9,20,24}$.

Trigeminal neuralgia is the most common type of neuropathic pain of the stomatognathic system. It is 
difficult to determine the prevalence because the disease is often not recognized as neuralgia; hence symptomatology is in dental practice initially related to odontogenic pain of unclear etiology. The complete and conclusive diagnostics as well as treatment procedures are the responsibility of a neurologist ${ }^{8}$. Also, his responsibility is co-morbidity of trigeminal neuralgia or pain related to trigeminal neuralgia and many systemic diseases which may induce orofacial pains (TMDs) or whether trigeminal neuralgia is an accompanying condition to the main disease (metabolic and endocrine diseases, rheumatic diseases, etc. $)^{27,28}$.

The Michigan splint is a form of non-violent orthopedic stabilization of the jaw joints by changing and correcting relationships of occlusion ${ }^{6}$. Physical therapy is a recommended modality for TMJ pain treatment. Since oral NSAIDs run a high risk for complications, topical forms of NSAID seem to be a useful complementary therapy of TMDs ${ }^{7}$.

\section{Conclusion}

Over the past period, clinical management of $\mathrm{pa}^{-}$ tients with orofacial pain has been developed with complementary medical disciplines specialists. The patients who were willing to participate (84.4\%) were treated in the study. The most numerous diagnoses were disc displacement (30.6\% of patients) and osteoarthritis of TMJ (41.9\% of patients). The higher proportion of female patients per diagnostic subgroup ranged from 14.2:1 for osteoarthritis of TMJ to 2.5:1 for myofascial pain of masticatory muscles. A statistically significant correlation was found for the variables of age, VAS pain, and duration of orofacial pain prior to first examination. The initial diagnosis and planning of further therapies in the form of multidisciplinary co-operation could be carried out by a dental prosthodontist possessing subspecialist knowledge of orofacial pain.

\section{References}

1. Jerolimov V. Temporomandibular disorders and orofacial pain. Rad 504 Medical sciences 2009;33:53-77.

2. Šklebar D, Šklebar I, Cesarik M, Barada A, Maletić A. Neuropathic orofacial pain - diagnostic and therapeutic challenges. Period Biol. 2015;117:231-7.

3. Palla S. Myoarthropatischer Schmerz: oft verkannt [Musculararthroscopic pain: often unappreciated]. Schmerz. 2003;17: 425-31. DOI: 10.1007/s00482-003-0254-6
4. Bag AK, Gaddikeri S, Singhal A, Hardin S, Tran BD, Medina JA, Curé JK. Imaging of the temporomandibular joint: An update. World J Radiol. 2014;6:567-82. DOI: 10.4329/wjr.v6. i8.567.

5. Alanen P. Etiology, evidence, and ethics: the problem of irreversible treatments of TMD. J Craniomand Func. 2018;10: 103-115.

6. Niemelä K, Korpela M, Raustia A, Ylöstalo P, Sipilä K. Efficacy of stabilisation splint treatment on temporomandibular disorders. J Oral Rehabil. 2012;39:799-804. DOI: $10.1111 / \mathrm{j} .1365-2842.2012 .02335 . x$.

7. Krapac L, Badel T. Disorder of temporomandibular joint - a rheumatological and physiatric approach. Rad HAZU Medicinske znanosti. 2010;34:97-109.

8. Bašić Kes V, Zadro Matovina L. Accommodation to Diagnosis of Trigeminal Neuralgia Acta Clin Croat. 2017;56:157-61. DOI: 10.20471/acc.2017.56.01.21.

9. Renton T. Chronic Pain and Overview or Differential Diagnoses of Non-odontogenic Orofacial Pain. Prim Dent J. 2019; 7:71-86.

10. Badel T. Temporomandibularni poremećaji i stomatološka protetika. Zagreb: Medicinska naklada, 2007.

11. Lajnert V, Gržić R, Kovačević Pavičić D, Bakarčić D, Badel T, Petričević N. Uporaba DKI/TMP protokola u dijagnostici temporomandibularnih poremećaja (TMP-a). Medicina Flum. 2009;45:56-9.

12. Türp JC. Vorstellung der Achse-I-Klassifikation. Craniomand Func. 2014;6:231-9.

13. Spielberger, C.D. Priručnik za upitnik anksioznosti kao stanja i osobine ličnosti STAI. Jastrebarsko: Slap; 2001.

14. Morović-Vergles J. Svjetski dan artritisa i desetogodišnjica djelovanja Hrvatskog nacionalnog odbora Desetljeća kostiju i zglobova. Medix. 2014;20:51-52.

15. Hladnik A, Bičanić I, Petanjek Z. Functional neuroanatomy of nociception and pain. Period Biol. 2015;117:195-204.

16. Türp JC. Failure in chronic pain therapy across the disciplines. Craniomand Func. 2017;9:197-208.

17. Badel T, Bago Jurič I, Fugošić V, Zajc I, Carek A, Zadravec D. Undergraduate Students' Knowledge on Temporomandibular Disorders in Croatia. Acta Clin Croat 2017; 56:460-8. DOI: 10.20471/acc.2017.56.03.13

18. Learreta JA, Matos JL, Matos MF, Durst AC. Current diagnosis of temporomandibular pathologies. Cranio. 2009;27:125-33. DOI: $10.1179 /$ crn.2009.019

19. Badel T, Savić Pavičin I, Krapac L, Zadravec D, Rosić D. Psoriatic arthritis and temporomandibular joint involvement - literature review with a reported case. Acta Dermatovenerol Croat. 2014;22:114-121.

20. Karibe H, Goddard G, McNeill C, Shih ST. Comparison of patients with orofacial pain of different diagnostic categories. Cranio. 2011;29:138-43. DOI: 10.1179/crn.2011.022

21. Badel T, Kocijan Lovko, S, Zadravec, D. Anxiety and Temporomandibular disorders: a Relationship in Chronic Pain Development. In: Shiloh AR (ed): Anxiety disorders - Risk Factors, 
Genetic Determinants and Cognitive-Behavioral Disorders. New York: Nova Science Publishers, 2014. pp.93-123

22. Badel T, Čimić S, Munitić M, Zadravec D, Bašić Kes V, Kraljević Šimunković S. Clinical view of the temporomandibular joint disorder. Acta Clin Croat. 2014;53:462-70.

23. De La Torre Canales G, Câmara-Souza MB, Muñoz Lora VRM, Guarda-Nardini L, Conti PCR, Rodrigues Garcia RM, Del Bel Cury AA, Manfredini D. Prevalence of psychosocial impairment in temporomandibular disorder patients: A systematic review. J Oral Rehabil. 2018;45:881-9. DOI: 10.1111/ joor.12685.

24. Badel T, Savić Pavičin I, Bašić Kes V, Zavoreo I, Zadravec D, Kern J. Orofacial pain caused by trigeminal neuralgia and/or temporomandibular disorders. Period Biol, 2013;115:185-9.
25. Yadav S, Yang Y, Dutra EH, Robinson JL, Wadhwa S. Temporomandibular Joint Disorders in Older Adults.J Am Geriatr Soc. 2018;66:1213-7. DOI: 10.1111/jgs.15354.

26. Brajković B, Macan D. Analysis of Emergency Cases in the Clinic of Maxillofacial and Oral Surgery, Clinical Hospital "Dubrava". Acta Stomatol Croat 2002;36:213-217.

27. Cesarik M, Zavoreo I, Zadro-Matovina L, Madžar T, Bašić Kes V. The Role of Electromyographic Blink Reflex in the Evaluation of Headache Incidence. Acta Clin Croat. 56:44-7. DOI: 10.20471/acc.2017.56.01.07

28. Badel T, Laškarin M, Zadravec D, Čimić S, Savić Pavičin I. Subluxation of temporomandibular joint- A clinical view. J Dent Probl Solut 2018;5: 029-034. DOI: 10.17352/23948418.000060

Sažetak

\section{OROFACIJALNA BOL: DIJAGNOSTIČKI I TERAPIJSKI IZAZOVI}

\section{T. Badel, D. Zadravec, V. Bašić Kes, M. Smoljan, S. Kocijan Lovko, I. Zavoreo, L. Krapac i S. Anić Milošević}

Već desetljećima se razvija koncepcija dijagnostike i terapije muskuloskeletalnih i neuropatskih bolesti stomatognatskog sustava, što je predmet ovog članka. Kako bi se izbjegle nedoumice može se reći da orofacijalni bolovi kao klinički problem obuhvaćaju u užem smislu ne-odontogene i ne-maligne uzroke bolova orofacijalne regije. U ovom članku evaluirani su rezultati kliničke dijagnostike populacije od 557 konsekutivnih pacijenata s orofacijalnim bolovima temeljem multidisciplinarne dijagnostike. Od sudjelovanja u studiji odustalo je 15,6\% pacijenata. Za pacijente koji su odustali od istraživanja pokazalo se da su bili značajnije stariji ( $\mathrm{p}=0,0411)$ od onih koji su pristali sudjelovati, ali nije bilo razlike u omjeru spola $(\mathrm{p}=0,185)$, jer je prevladavao udio ženskih pacijenata. U analizi 84,4\% pacijenata koji su sudjelovali u studiji utvrđene su povišene vrijednosti anksioznosti (prosjek STAI 1 je bio 39,2, a na STAI 2 je bio 41,1), te se je pokazala statistička značajnost u ovisnosti povišene anksioznosti s intenzitetom bolova na vizualno-analognoj skali pri otvorenim ustima ( $\mathrm{p}<0,0001)$. U odnosu na dob statistička značajnost bilo je za STAI $1(\mathrm{p}=0,0097)$ ali ne i za STAI $2(\mathrm{p}=0,5599)$. Najčešći oblik terapije je michiganska stabilizacijska udlaga: za pomak diska temporomandibularnog zgloba (TMZ) kod 38,9\% i u kombinaciji s fizioterapijom kod 18,7\% pacijenata; za osteoartritis TMZ-a kod 28,4\% i u kombinaciji sa fizioterapijom kod 26,4\% pacijenata. Za trigeminalnu neuralgiju prevladava kod 54,3\% liječenje sa antikonvulzivima, u kombinaciji s akupunkturom $25,7 \%$ te samo akupunktura kod 17,1\% pacijenata. Multidisciplinarna suradnja u inicijalnoj dijagnostici i diferencijalnoj dijagnostici u ovoj studiji osmišljena je u svrhu razvijanja subspecijalističkog znanja o orofacijalnim bolovima.

Ključne riječi: orofacijalna bol, temporomandibularni zglob, anksioznost, neuralgija trigeminusa 